\title{
Stocks of carbon, total nitrogen and humic substances in soil under different cropping systems
}

\section{Estoques de carbono e nitrogênio totais nas substâncias húmicas do solo sob diferentes sistemas de manejo}

\author{
Diovany Doffinger Ramos ${ }^{1 *}$; Eulene Francisco da Silva ${ }^{2}$; \\ Simone Cândido Ensinas ${ }^{3}$; Natália Hilgert de Souza ${ }^{3}$; \\ Douglas Costa Potrich ${ }^{3}$; Mirianny Elena de Freitas ${ }^{3}$; \\ Anelise Samara Nazari Formagio ${ }^{1}$; Maria do Carmo Vieira ${ }^{4}$
}

\begin{abstract}
This study aimed to evaluate total carbon and nitrogen and stocks of the humic fractions of soil organic matter under different cropping systems at the experimental farm at the Federal University at Grande Dourados - UFGD. Soil samples were collected from two layers $(0-10$ and $10-20 \mathrm{~cm})$ from an oxisol with a clay texture. The systems studied were as follows: non-tillage (NTS), tillage (TS), eucalyptus and pasture. Natural vegetation from Dourados, Mato Grosso do Sul, Brazil was used for comparison. For statistical analysis of the $\mathrm{C}$ and $\mathrm{N}$ stocks, the model: $\mathrm{Y}=\mu+\mathrm{Ai}+\operatorname{rep}(\mathrm{A}) \mathrm{ik}+$ Eijk was used. The replacement of TN one for CT decreased the total organic carbon and $\mathrm{C}$ in the stocks of humic substances (fulvic acid, humic acid and humin) in the soil just three years after adoption, especially in the $0-10 \mathrm{~cm}$ layer. However, soils under eucalyptus trees acquired increased carbon stock in the most active fractions, such as the fractions of fulvic and humic acids $(0-20 \mathrm{~cm}$ layer). Regardless of the cropping system, the largest $\mathrm{C}$ and $\mathrm{N}$ stocks were measured for the humin fraction, followed by humic acid and fulvic acid. The total $\mathrm{N}$ and humic and fulvic acid levels under the conditions of maintenance of TN for 15 years increased when compared with $\mathrm{CT}$, but not in soils under eucalyptus trees.
\end{abstract}

Key words: Oxisol, non-tillage, humic acid, fulvic acid

\section{Resumo}

O objetivo deste trabalho foi determinar os estoques de $\mathrm{C}$ e $\mathrm{N}$ totais nas frações húmicas da matéria orgânica, em diferentes sistemas de manejo do solo na fazenda experimental da Universidade Federal da Grande Dourados - UFGD. Para isso, foram coletadas amostras (0-10 e 10-20 cm) em um Latossolo Vermelho distroférrico, textura argilosa, nos sistemas de plantio direto (SPD) e convencional (SPC), e os solos cultivados com pastagem e com eucalipto, como referência foi utilizado solo coletado em área de floresta nativa, em Dourados-MS. Para análise estatística dos estoques de $\mathrm{C}$ e $\mathrm{N}$ foi utilizado o modelo estatístico: $\mathrm{Y}=\mu+\mathrm{Ai}+\operatorname{rep}(\mathrm{A}) \mathrm{ik}+$ Eijk. A substituição do sistema SPD pelo SPC resultou em perdas no COT e $\mathrm{C}$ das substancias húmicas (ácido fúlvico, húmico e humina) no solo em apenas três anos de adoção, principalmente na profundidade de $0-10 \mathrm{~cm}$, todavia, quando substituído pelo eucalipto

\footnotetext{
${ }^{1}$ Pesquisadores Drs. da Universidade Federal da Grande Dourados, UFGD, Dourados, MS. E-mail: diovany3@hotmail.com; aneliseformagio@ufgd.edu.br

${ }^{2}$ Prof $^{a}$ Dr $^{\mathrm{a}}$. da Universidade Federal Rural do Semi-Árido, UFERSA, Mossoró, RN. E-mail: eulene_silva@yahoo.com.br

${ }^{3}$ Discentes do curso de Pós-Graduação em Agronomia, UFGD, Dourados, MS. E-mail: simone_candido@hotmail.com; natalia_ hilgert@hotmail.com; douglas_potrich@hotmail.com; miriannyelena@hotmail.com

${ }^{4}$ Prof $^{\mathrm{a}} \mathrm{Dr}^{\mathrm{a}}$ da Universidade Federal da Grande Dourados, UFGD, Dourados, MS. E-mail: vieiracm@terra.com.br

* Author for correspondence
} 
proporcionou aumento do estoque de $\mathrm{C}$ em frações mais ativas, como frações de ácido húmico e fúlvico $(0-20 \mathrm{~cm})$. Independente do sistema de manejo ou uso do solo, os maiores estoques de $\mathrm{C}$ e $\mathrm{N}$ foram para a fração humina, seguida do ácido húmico e ácido fúlvico. Para o $\mathrm{N}$ total e N-AH e N-AF a permanência do SPD por 15 anos, promoveu aumento em relação ao SPC, todavia não constatou-se essa diferença com eucalipto.

Palavras-chave: Latossolo, plantio direto, ácidos humicos, ácidos fúlvicos

\section{Introduction}

Over the last few decades, new systems of agricultural production have been developed that are based on soil conservation, crop diversification and the recycling of nutrients, in an attempt to balance agricultural productivity with environmental conservation and to improve soil by increasing organic carbon (OCS) (BAYER, 2000). Nontillage techniques (NTS), by disturbing soil only in the planting rows, and by using crop rotation and maintaining crop residues on the soil surface, provide for a slow and gradual decomposition of plant materials which, coupled with the existing mineral fractions in the soil, favor the accumulation of soil organic matter (SOM) (SÁ et al., 2001). While studying the annual accumulation of $\mathrm{C}$ in cultivated soils under NTS throughout Brazil, Bernoux et al. (2006) estimated a balance of -0.5 to $0.9 \mathrm{t} \mathrm{ha}^{-1}$ year $^{-1}$, with a positive mean value of $0.65 \mathrm{t}$ ha $^{-1}$ year $^{-1}$ when compared with tillage systems (TS) using soil disturbance. The differences were due to weather, the type of plant used in the rotations, and soil texture, among other factors.

While evaluating the effects of different cropping systems, Siqueira Neto et al. (2009a) studied the relationship between total carbon and the chemical attributes of an oxisol in the cerrado region of Rio Verde and found the highest levels of soil carbon under an NTS $\left(20 \mathrm{~g} \mathrm{~kg}^{-1}\right)$ when compared with a TS $\left(15 \mathrm{~g} \mathrm{~kg}^{-1}\right)$ at least in the 0.00 to $0.40 \mathrm{~m}$ depth layer of soil. Siqueira Neto et al. (2009b) studied crop rotations under NTS and carbon sequestration in the soils. Tibagi (PR) found that sequestration of liquid $\mathrm{CO}_{2}$ under NTS was approximately $6.0 \mathrm{tha}^{-1}$ year ${ }^{-1}$. Silva and Mielniczuk (1997) found that in some situations where pastures had been managed improperly, the soil under Gramineae exhibited the lowest $\mathrm{C}$ stocks when compared with native vegetation. Nevertheless, in pasture areas that had been managed correctly, the amount of SOM exceeded the amount typically found in areas with native vegetation (CERRI et al., 2004).

Replacement of native vegetation in the cerrado region by eucalyptus plantations can lead to changes in $\mathrm{C}$ stocks and in various SOM fractions. In soils collected near Eucalyptus urophylla growing in settlements, Pulrolnik et al. (2009) observed that 20-year-old eucalyptus plantations exhibited a total organic carbon (TOC) content similar to that found in cerrado vegetation and in pastured areas. In the recalcitrant fractions considered, the $\mathrm{C}$ contents of humic acid and fulvic acid, respectively, were $16.6 \%$ and $17.5 \%$ higher for the eucalyptus soil compared to the pasture, and $17.5 \%$ and $36.9 \%$ compared to the cerrado.

The analysis of humic substances (humin fraction, humic acid and fulvic acid) in various cropping systems is important because these substances are considered to be more stable and are difficult to chemically degrade; thus, they represent the pool of C in soil (LOSS et al., 2010).

The study of TOC also influences the dynamics of nitrogen in the soil because its main reserve in the soil is the SOM, which has great significance for the supply of this nutrient to crops. There is a need to compare the results for different soil cropping systems as well as for the accumulation of $\mathrm{C}$ and $\mathrm{N}$ and of humified SOM fractions. Studies have also been lacking on the adoption time of a specific type of soil preparation and crop rotation, while considering the local weather conditions; additionally, most literature has studied the south 
and southeast of Brazil. Therefore, this study aimed to measure the stocks of total $\mathrm{C}$ and $\mathrm{N}$ and of humic substances (fulvic acids, humic acids and humin) from SOM under different cropping systems.

\section{Materials and Methods}

The research was performed in May 2010, at the Experimental Farm for Agricultural Sciences (FAECA) at the Federal University of Grande Dorados (UFGD) in Dourados, MS. This farm is located at a latitude of $22^{\circ} 14^{\prime} 16^{\prime \prime} \mathrm{S}$ and a longitude of $54^{\circ} 49^{\prime} 2^{\prime \prime} \mathrm{W}$, with an average altitude of 452 $\mathrm{m}$. The climate is Cwa, according to Köppen, with precipitation totals and maximum and minimum temperature averages of $1,450 \mathrm{~mm}, 29.4^{\circ} \mathrm{C}$ and 17.4 ${ }^{\circ} \mathrm{C}$, respectively. In all of the cropping systems, the soil was classified as an oxisol, composed primarily of clay oxides and hydroxides of Fe and Al, and it had a flat topography. The systems studied were as follows: non-tillage, tillage, pasture and eucalyptus. Natural vegetation was used for comparison and was located approximately $800 \mathrm{~m}$ away from the areas under study, totaling five areas distributed over a range of homogeneous soils. The histories of these areas are shown in Table 1.

Table 1. History of cropping systems in an oxisol.

Cropping

system
Historic
Native vegetation

Nontillage

Tillage

Pasture

Eucalyptus
Area with natural vegetation without human action used as a reference ecosystem of the region.

Area planted with crops in no-tillage for 15 years, growing soybeans in the summer and winter maize (second season) and was not used another practice for formation of straw. Fertilization and liming followed the recommendations of each culture, being soil collected performed on the remaining of soybean straw.

Area planted with crops in no-tillage for 11 years, and in 2007 to the current period was chosen tillage, consisted of one plowing and two diskings. The rotation system is similar to no-till soybean and corn, and fertilization and liming followed the recommendations of each culture, and collecting soil also performed on the remainder of soybean straw.

Area covered with pasture, established 15 years ago with signalgrass (Urochloa decumbens (Stapf) RD Webster), with liming and fertilization performed only in its deployment and use of 0.5 animal unit (AU) per hectare per year. Area showed signs of degradation.

Area previously occupied in no-till farming for 11 years, and in 2007 was planted seedlings of Eucalyptus. The planting was done in $3 \times 3 \mathrm{~m}$ spacing. Fertilization and correction were performed only at planting.

Source: Elaboration of the authors.

For each cropping system evaluated, we selected an area of one (1) ha, and this area was defined as the plot. Existing straw was removed from the soil surface, and soil samples were collected at depths of 0-10 and 10-20 cm. At each sampling point, with five repetitions ( 5 points/plot), trenches were opened measuring $30 \times 30 \times 40 \mathrm{~cm}$ (width, length and depth, respectively), and sampling was performed.

For the extraction of humic substances (HSs), samples of air-dried soil (ADS) were crushed, passed through a 60 mesh $(0.210 \mathrm{~mm})$ sieve and 
subjected to fractionation using the method of the International Humic Substances Society (IHSS) (SWIFT, 2001). The fractions obtained were fulvic acids (FA), humic acids (HA) and humin (Hum), depending on their differential solubilities in acid and alkaline solutions. The determination of total carbon and of the fractions of HSs was performed using the wet oxidation method with external warming, as proposed by Yeomans and Bremner (1988), and nitrogen levels were determined by Kjeldahl distillation (BREMNER, 1996). Stocks of $\mathrm{C}$ and $\mathrm{N}$ were obtained by multiplying the content $\left(\mathrm{g} \mathrm{kg}^{-1}\right)$ of the element by the mass of the soil from each layer studied $\left(\mathrm{kg} \mathrm{ha}^{-1}\right)$. The mass of the soil was derived by multiplying the thickness of each layer $(\mathrm{m})$, by its density $\left(\mathrm{kg} \mathrm{dm}^{-3}\right)$ and the volume of the soil $\left(\mathrm{dm}^{-3}\right)$, and the final sum was obtained stock to $\mathrm{C}$ layer of $20 \mathrm{~cm}$. Soil density $\left(\mathrm{kg} \mathrm{dm}^{-3}\right)$ was determined using the volumetric ring method after Embrapa (1997) for 0-10 and 10-20 cm of soil depth.

Statistical analysis of the stocks of $\mathrm{C}$ and $\mathrm{N}$ was performed using the statistical model: $\mathrm{Y}=\mu+\mathrm{Ai}$ $+\operatorname{rep}(\mathrm{A})+\mathrm{ik}$ eijk, for which $\mu$ : overall mean, $\mathrm{A}$ : cropping systems $(\mathrm{i}=1,2,3,4,5), \operatorname{rep}(\mathrm{A})=\operatorname{rep}(\mathrm{k}$ $=1,2,3,4,5)$ and $\varepsilon$ : experimental error. In cases of significance, an analysis of variance was used with the Scott-Knott test $(\mathrm{p}<0.05)$, using the computer application SAEG 9.1 (RIBEIRO JÚNIOR; MELO, 2008).

\section{Results and Discussion}

The total organic carbon (TOC) and total nitrogen $(\mathrm{TN})$ stocks were significantly $(\mathrm{p}<0.05)$ influenced by the cropping systems in all of the layers evaluated (Table 2).

Table 2. Stocks of organic carbon and total nitrogen under different cropping systems.

\begin{tabular}{lccc}
\hline \multirow{2}{*}{ Cropping systems } & \multicolumn{3}{c}{ Layers $(\mathrm{cm})$} \\
\cline { 2 - 4 } & $0-10$ & $10-20$ & $0-20$ \\
\hline Native vegetation & $39.71 \mathrm{a}$ & Total organic carbon stock $\left(\mathrm{t} \mathrm{ha}^{-1}\right)$ & $76.88 \mathrm{a}$ \\
Nontillage & $24.06 \mathrm{~b}$ & $37.17 \mathrm{a}$ & $51.79 \mathrm{c}$ \\
Conventional tillage & $36.88 \mathrm{a}$ & $27.72 \mathrm{~b}$ & $62.74 \mathrm{~b}$ \\
Pasture & $33.32 \mathrm{a}$ & $25.86 \mathrm{~b}$ & $62.00 \mathrm{~b}$ \\
Eucalyptus & $35.98 \mathrm{a}$ & $28.68 \mathrm{~b}$ & $61.28 \mathrm{~b}$ \\
& & $25.30 \mathrm{~b}$ & \\
Native vegetation & $2.50 \mathrm{a}$ & Stock of total nitrogen $\left(\mathrm{t} \mathrm{ha}{ }^{-1}\right)$ & $4.95 \mathrm{a}$ \\
Nontillage & $1.47 \mathrm{~b}$ & $2.45 \mathrm{a}$ & $3.18 \mathrm{c}$ \\
Conventional tillage & $2.36 \mathrm{a}$ & $1.71 \mathrm{~b}$ & $3.88 \mathrm{~b}$ \\
Pasture & $2.38 \mathrm{a}$ & $1.52 \mathrm{~b}$ & $3.99 \mathrm{~b}$ \\
Eucalyptus & $2.14 \mathrm{a}$ & $1.61 \mathrm{~b}$ & $3.77 \mathrm{~b}$ \\
\hline
\end{tabular}

Within each layer, means followed by same letter do not differ by Scott-Knott $(\mathrm{p}<0.05)$.

Source: Elaboration of the authors.

The stock of TOC under tillage systems (TS) was $34.8 \%$ lower when compared with non-tillage systems (NTS), and NTS did not differ from native vegetation, pastures or eucalyptus for the $0-10 \mathrm{~cm}$ layer. These results were related to the constant turning of the soil under the tillage system and to the optimal conditions for aeration, which favor the rapid decomposition of organic matter (FONTANA 
et al., 2006; VEZZANI; MIELNICZUK, 2011). The highest TOC values were observed in the NTS, native vegetation, pasture and eucalyptus systems, which are associated with higher inputs, and continuously form organic materials with different degrees of susceptibility to decomposition (CARDOSO et al., 2011; STEINER et al., 2012). We also noted, in this study, that even where minimum tillage had been implemented for 15 years in a typical oxisol and TS had been used during the most recent four years, Rangel and Silva (2007) observed that with maize cultivation in summer followed by winter beans, there were reductions of $20 \%$ in TOC in the TS compared with the NTS for the $0-10 \mathrm{~cm}$ layer. However, at greater depths $(10-20 \mathrm{~cm})$, no differences were found between cropping systems, with $\mathrm{C}$ stock predominating in the native vegetation (37.17 $\mathrm{t} \mathrm{ha}^{-1}$ ) (Table 2). Smaller losses of TOC in the 10-20 cm layer under TS might be associated with the incorporation of plant residues produced by the action of the disk harrow, used in preparing the soil, which increased the $\mathrm{C}$ input to the soil. The reductions of TOC in the TS, NTS, pasture and eucalyptus when compared with the reference system (native vegetation) were $25.4 \%, 30.4 \%$, $22.8 \%$ and $31.9 \%$, respectively (Table 2 ). The higher concentration of TOC in the area under native vegetation was due to the constant input of $\mathrm{C}$ via litter and rhizodeposition (SOUZA et al., 2006), and the fact that the soil structure was preserved, which contributed, via aggregation, to the protection and maintenance of soil C (CARNEIRO et al., 2009). In the analysis of TOC throughout the layers (0$20 \mathrm{~cm}$ ), although the largest stocks were measured under native vegetation (76.88 $\left.\mathrm{t} \mathrm{ha}^{-1}\right)$, there was a $17 \%$ increase in carbon stocks when using NTS compared with TS (Table 2). In a similar case, in an oxisol (at 0-20 cm), D'Andrea et al. (2004) found C stocks to be lower for native vegetation $\left(38 \mathrm{t} \mathrm{ha}^{-1}\right)$, pasture (15 years planted with Urochloa decumbens) (41 $\mathrm{t} \mathrm{ha}^{-1}$ ) and TS (4 years - $38 \mathrm{t} \mathrm{ha}^{-1}$ ) than for $\mathrm{C}$ stocks found in this study. Most likely, these differences were related to climatic factors because the systems are similar to those in this study. The portion of the study in the cerrado region, however, was conducted in a seasonal tropical savanna (Aw in the Köppen system).

The stock of total nitrogen (TN) was affected similarly, as was the stock of TOC by the various cropping systems, with the highest values being found in native vegetation $\left(2.5,2.45\right.$ and $4.95 \mathrm{t} \mathrm{ha}^{-1}$ for layers at 0-10, 10-20 and 0-20 cm, respectively) (Table 2). With respect to cropping systems, the permanence of the NTS over 15 years, growing soybeans/corn, promoted an increase of 37.7 and $18.0 \%$ in the $0-10$ and $0-20 \mathrm{~cm}$ layers, respectively, compared with the TS, but no differences were observed relative to the soil growing pasture or eucalyptus (Table 2). As $95 \%$ of the $\mathrm{TN}$ in soil is present in organic form, changes in the stocks of TOC imply changes in the availability of TN (D'ANDREA et al., 2004). This process is regulated in part by the cropping systems themselves, and by systems such as NTS, eucalyptus and pasture, with greater production of plant biomass, the retention of straw or litter on the soil surface and large quantities of roots causing larger stocks of TN (D'ANDRÉA et al., 2004; COSTA et al., 2008; CARNEIRO et al., 2009; SIQUEIRA NETO et al., 2009b).

Carbon stocks from the fulvic acid carbon (CFA), humic acid carbon (C-HA) and humin carbon (C-Hum) fractions were affected significantly ( $p$ $<0.05$ ) by cropping systems in all of the layers evaluated. The highest levels of $\mathrm{C}$ stocks belonged to the humin fraction, followed by humic acid and fulvic acid (Table 3). Silva and Mendonça (2007) reported that these three represented the principal fractions of TOC of the soil. Humin represents approximately $30-80 \%$ of the total, depending mainly on texture, and being higher in soils with higher clay content. The largest stocks of C-Hum can be attributed to the interactions of humin with the mineral fraction of the soil, which has a high proportion of clay. Fontana et al. (2001) studied the behavior of SOM oxisol and acrisol in Campos dos Goytacazes under various vegetation covers and found higher mean values for the humin 
fraction in oxisols, indicating a greater resistance to decomposition of this fraction due to more stable links with the mineral fraction of the soil. Pinheiro et al. (2003) studied clay oxisols and different cropping systems using tillage (such as conventional tillage), various preparation levels and minimum tillage as well as soil with grass and without vegetable cover; they observed a predominance of the humin fraction above $81 \%$ compared to other fractions.

Table 3. Carbon stock fractions of fulvic acid, humic acid and humin under different cropping systems.

\begin{tabular}{lccc}
\hline \multirow{2}{*}{ Cropping systems } & \multicolumn{3}{c}{ Layers $(\mathrm{cm})$} \\
\cline { 2 - 4 } & $0-10$ & $10-20$ & $0-20$ \\
\hline Native vegetation & $1.17 \mathrm{~b}$ & Carbon stocks fulvic acid $\left(\mathrm{t} \mathrm{ha}^{-1}\right)$ & $2.28 \mathrm{c}$ \\
Nontillage & $0.95 \mathrm{c}$ & $1.11 \mathrm{c}$ & $2.06 \mathrm{c}$ \\
Tillage & $1.29 \mathrm{~b}$ & $1.11 \mathrm{c}$ & $2.34 \mathrm{c}$ \\
Pasture & $1.66 \mathrm{a}$ & $1.05 \mathrm{c}$ & $3.14 \mathrm{~b}$ \\
Eucalyptus & $1.03 \mathrm{c}$ & $1.48 \mathrm{~b}$ & $3.47 \mathrm{a}$ \\
& & $2.44 \mathrm{a}$ & \\
Native vegetation & $3.10 \mathrm{~b}$ & Carbon stocks humic acid $\left(\mathrm{t} \mathrm{ha}^{-1}\right)$ & $6.58 \mathrm{a}$ \\
Nontillage & $2.49 \mathrm{c}$ & $3.47 \mathrm{a}$ & $5.76 \mathrm{~b}$ \\
Tillage & $3.34 \mathrm{~b}$ & $3.27 \mathrm{a}$ & $6.17 \mathrm{~b}$ \\
Pasture & $3.73 \mathrm{a}$ & $2.83 \mathrm{~b}$ & $6.87 \mathrm{a}$ \\
Eucalyptus & $3.23 \mathrm{~b}$ & $3.14 \mathrm{a}$ & $5.73 \mathrm{~b}$ \\
& & $2.51 \mathrm{~b}$ & \\
Native vegetion & $9.61 \mathrm{a}$ & Carbon stocks humin $\left(\mathrm{t} \mathrm{ha} \mathrm{C}^{-1}\right)$ & $19.79 \mathrm{a}$ \\
Nontillage & $6.33 \mathrm{c}$ & $9.18 \mathrm{a}$ & $13.79 \mathrm{c}$ \\
Tillage & $9.67 \mathrm{a}$ & $7.46 \mathrm{~b}$ & $16.99 \mathrm{~b}$ \\
Pasture & $8.26 \mathrm{~b}$ & $6.32 \mathrm{~b}$ & $16.31 \mathrm{~b}$ \\
Eucalyptus & $9.69 \mathrm{a}$ & $8.05 \mathrm{a}$ & $16.39 \mathrm{~b}$ \\
\hline
\end{tabular}

Within each layer, means followed by the same letter do not differ by Scott-Knott $(\mathrm{p}<0.05)$.

Source: Elaboration of the authors.

After analyzing the carbon stocks for the C-AF and $\mathrm{C}-\mathrm{AH}$ fractions, it was observed that the largest stocks were found in soils under pasture (1.66 and $\left.3.74 \mathrm{tha}^{-1}\right)$ in the $0-10 \mathrm{~cm}$ layer and for humic acid (3.14 $\mathrm{tha}^{-1}$ ) in the 10-20 cm layer (Table 3). This result is most likely attributable to the more highly developed and extensively distributed root systems found in grass (Urochloa decumbens), which favor high deposition of carbon into the soil from the roots. Rasse, Rumpel and Dignac (2005) reported that the permanence time for soil $\mathrm{C}$ derived from roots is 2.4 times higher when compared with the carbon derived from the shoot biomass and that only a quarter of that amount can be explained by the higher chemical recalcitrance of these tissues. This finding further suggests that other protection mechanisms are strengthened by the activity of roots, including the following: physical and chemical protection, physical protection on a micrometric scale through the activity of mycorrhizae and root hairs and chemical interactions with metal ions from higher levels of cation exchange capacity, as in the case of humic and fulvic acids.

The sum profile (for $0-20 \mathrm{~cm}$ ) was higher for stocks in soils under eucalyptus cultivation for both the $\mathrm{C}-\mathrm{AF}$ and $\mathrm{C}-\mathrm{AH}$ fractions $(3.47$ and $6.87 \mathrm{tha}$ 
${ }^{1}$, respectively) (Table 3 ). The eucalyptus area had previously been occupied by plantations practicing non-tillage for 11 years, planting soybeans/corn, and being rotated with the planting of eucalyptus seedlings every 4 years, the fact of having a revolving least assisted by litter deposited on the soil surface, most likely permitted the accumulation of humified SOM fractions over a wider layer (0-20 $\mathrm{cm})$. In the cerrado region of Vale do JequitinhonhaMG, Pulrolnik et al. (2009) observed that 20-yearold eucalyptus plantations had TOC levels similar to those of both cerrado vegetation and pasture, for the humic acid and fulvic acid fractions. The levels of $\mathrm{C}$ were $16.6 \%$ and $17 \%$, respectively, which are $5 \%$ higher for the soil under eucalyptus compared with soils under pasture, and $17.5 \%$ and $36.9 \%$ for the cerrado soils, respectively.

By analyzing various cropping systems, we observed that NTS performed better, using our criteria, than did TS for fractions of C-FA, C-HA and C-Hum, by $26.3 \%, 25.5 \%$ and $33.9 \%$, respectively, mainly in the $0-10 \mathrm{~cm}$ layer. These results might be related to the physical protection of organic compounds from microbial decomposition, which is favored by the occlusion of carbon in soil aggregates and the chemical protection of organic compounds by means of their interaction with soil minerals and ions, when submitted to a more conservationoriented management system. With reference to stocks of $\mathrm{N}$ in the SOM fractions, there was no difference in the $0-10 \mathrm{~cm}$ layer between any of the systems under study for N-FA or N-HA. However, there was a higher accumulation of N-FA in the NTS (1.25 and $1.69 \mathrm{tha}^{-1}$ ) for the $10-20 \mathrm{~cm}$ and $0-20 \mathrm{~cm}$ layers, respectively, indicating greater mobility of $\mathrm{N}$ at depth for the no-till system. For N-HA, there was a gain of $23 \%$ for the NTS compared with the TS (for 0-20 cm), but there were no differences between the native vegetation, the pasture or the eucalyptus (Table 4). Under these conditions, it is possible that the largest amount of deposition of wastes from roots and shoots was produced primarily from rotations with legumes/grass and minimum revolving, which is associated with a lower $\mathrm{C} / \mathrm{N}$ ratio for soybeans in soils using the NTS, deposited over time under the soil and contributing to higher accumulations of $\mathrm{N}$ in the humic substances, mainly in the most active fractions of organic matter such as FA and HA. Stevenson (1994) emphasized the necessity of $\mathrm{N}$ for the synthesis of humic substances. Evidence suggests that it has important roles in humification and in the formation of stable organic compounds in soils (DIJKSTRA et al., 2004).

For the humin fraction, greater $\mathrm{N}$ stocks occurred in the native vegetation area $(1.43,0.77$ and $2.20 \mathrm{ha}^{-1}$ at $0-10,10-20$ and $0-20 \mathrm{~cm}$ of depth, respectively), followed by the eucalyptus and NTS and, subsequently, the TS and pasture (Table 4). Increments of $\mathrm{N}$ in the soil, such as those that occurred in native vegetation (Table 2), can reduce the production of enzymes (ligninolytic) that act in processes of microbial decomposition (CARREIRO et al., 2000) and increase the structural stabilization of humic substances, especially in the humin fraction, due to its reaction with $\mathrm{N}$-lignin residues and phenolic compounds, followed by the formation of recalcitrant compounds (SJÖBERG et al., 2004). 
Table 4. Nitrogen stock fractions of fulvic acid, humic acid and humin under different cropping systems.

\begin{tabular}{lccc}
\hline \multirow{2}{*}{ Cropping systems } & \multicolumn{2}{c}{ Layers $(\mathrm{cm})$} & $0-20$ \\
\cline { 2 - 4 } & $0-10$ & $10-20$ & $0.86 \mathrm{~b}$ \\
Native vegetation & $0.55 \mathrm{a}$ & Stocks of fulvic acid nitrogen $\left(\mathrm{t} \mathrm{ha}^{-1}\right)$ & $0.78 \mathrm{~b}$ \\
Nontillage & $0.39 \mathrm{a}$ & $0.31 \mathrm{~b}$ & $1.69 \mathrm{a}$ \\
Tillage & $0.45 \mathrm{a}$ & $0.40 \mathrm{~b}$ & $0.74 \mathrm{~b}$ \\
Pasture & $0.41 \mathrm{a}$ & $1.25 \mathrm{a}$ & $0.95 \mathrm{~b}$ \\
Eucalyptus & $0.44 \mathrm{a}$ & $0.33 \mathrm{~b}$ & \\
& & $0.51 \mathrm{~b}$ & $2.05 \mathrm{a}$ \\
Native vegetation & $0.92 \mathrm{a}$ & Stocks humic acid nitrogen $\left(\mathrm{t} \mathrm{ha}^{-1}\right)$ & $1.37 \mathrm{~b}$ \\
Nontillage & $0.67 \mathrm{a}$ & $0.14 \mathrm{a}$ & $1.79 \mathrm{a}$ \\
Tillage & $1.10 \mathrm{a}$ & $0.69 \mathrm{~b}$ & $1.88 \mathrm{a}$ \\
Pasture & $0.93 \mathrm{a}$ & $0.95 \mathrm{a}$ & $1.80 \mathrm{a}$ \\
Eucalyptus & $0.85 \mathrm{a}$ & $0.95 \mathrm{a}$ & \\
& & $1.51 \mathrm{a}$ & $3.30 \mathrm{a}$ \\
Native vegatation & $1.78 \mathrm{a}$ & $1.03 \mathrm{~b}$ & $1.97 \mathrm{c}$ \\
Nontillage & $0.94 \mathrm{c}$ & $0.77 \mathrm{c}$ & $2.20 \mathrm{c}$ \\
Tillage & $1.43 \mathrm{~b}$ & $0.81 \mathrm{c}$ & $1.90 \mathrm{c}$ \\
Pasture & $1.09 \mathrm{c}$ & $1.02 \mathrm{~b}$ & $2.52 \mathrm{~b}$ \\
Eucalyptus & $1.50 \mathrm{~b}$ & Stocks humin nitrogen $\left(\mathrm{t} \mathrm{ha} \mathrm{a}^{-1}\right)$ & \\
\hline
\end{tabular}

Within each layer, means followed by the same letter do not differ by Scott-Knott $(\mathrm{p}<0.05)$.

Source: Elaboration of the authors.

\section{Conclusions}

1. The replacement of NTS by TS resulted in losses in total organic carbon and $\mathrm{C}$ from humic substances (fulvic acid, humic and humin) in the soil after only three years of adoption, especially in the $0-10 \mathrm{~cm}$ layer.

2. The replacement of NTS by eucalyptus increased carbon stocks in the most active fractions, such as fractions of humic and fulvic acid, at the 0-20 cm layer.

3. Independent of the cropping systems, the largest stocks of $\mathrm{C}$ and $\mathrm{N}$ were found in the humin fraction, followed by humic acid and fulvic acid.

4. For total nitrogen, and especially for the humic and fulvic acid fractions, the use of an NTS for 15 years, using soybeans/corn, promoted an increase when compared to TS, but this difference was not found when the soil was cultivated with eucalyptus.

\section{Referências}

BAYER, C.; AMADO, T. J. C.; MIELNICZUK, J.; MARTIN NETO, L.; FERNANDES, S. V. Tillage and cropping system effects on organic matter storage in an Acrisol soil in southern Brazil. Soil and Tillage Research, Amsterdam, v. 54, n. 1-2, p. 101-109, 2000.

BERNOUX, M.; CERRI, C. C.; CERRI, C. E. P.; SIQUEIRA NETO, M.; METAY, A.; PERRIN, A. S.; SCOPEL, E.; RAZAFIMBELO, T.; BLAVET, D.; PICCOLO, M. C.; PAVEI, M.; MILNE, E. Cropping systems, carbon sequestration and erosion in Brazil, a review. Agronomy for Sustainable Development, France, v. 26, n. 1, p. 1-8, 2006.

BREMNER, J. M. Nitrogen total. In: SPARKS, D. L. Methods of soil analysis. America Society of Agronomy, Madison: SSSA Book Series, 1996, p. 1085-1121.

CARDOSO, E. L.; SILVA, M. L. N.; CURI, N.; FERREIRA, M. M.; FREITAS, D. A. F. Chemical and physical characteristics of the soil under native arboreous vegetation in the Pantanal South-Mato-Grosso. Revista Brasileira de Ciências do Solo, Viçosa, v. 35, n. 2, p. 613-622, 2011. 
CARNEIRO, M. A. C.; SOUZA, E. D.; REIS, E. F.; PEREIRA, H. S.; AZEVEDO, W. C. Physical, chemical and biological properties of cerrado soil under different use and management systems. Revista Brasileira de Ciências do Solo, Viçosa, MG, v. 33, n. 1, p. 147-157, 2009.

CARREIRO, M. M.; SINSABAUGH, R. L.; REPERT, D. A.; PARKHURST, D. F. Microbial enzyme shifts explain litter decay responses to simulated nitrogen deposition. Ecology, Washington, v. 81, n. 9, p. 2359-2365, 2000.

CERRI, C. E. P.; BERNOUX, M.; CHAPLT, V.; VOLKOFF, B.; VICTÓRIA, R. L.; MELILLO, J. M.; PAUSTIAN, K.; CERRI, C. C. Modeling changes in soil organic matter in Amazon Forest to pasture conversion with the Century model. Global Change Biology, Oxford, v. 10, n. 5, p. 815-832, 2004.

COSTA, F. S.; BAYER, C.; ZANATTA, J. A.; MIELNICZUK, J. Storage of soil organic carbon and emissions of carbon dioxide influenced by manegment systems in southern Brazil. Revista Brasileira de Ciências do Solo, Viçosa, MG, v. 32, n. 1, p. 323-332, 2008.

D’ANDRÉA, A. F.; SILVA, M. L. N.; CURI, N.; GUILHERME, L. R. G. Storage of carbon and nitrogen and forms of mineral nitrogen in a soil under different management systems. Pesquisa Agropecuária Brasileira, Brasília, v. 39, n. 2, p. 179-186, 2004.

DIJKSTRA, F. A.; HOBBIE, S. E.; KNOPS, J. M. H.; REICH, P. B. Nitrogen deposition and plant species interact to influence soil carbon stabilization. Ecology Letters, Oxford, v. 7, n. 12, p. 1192-1198, 2004.

EMPRESA BRASILEIRA DE PESQUISA AGROPECUÁRIA - EMBRAPA. National Survey and Soil Conservation. Manual methods of soil analysis. 2. ed. Rio de Janeiro, 1997. 212 p.

FONTANA, A.; PEREIRA, M. G.; LOSS, A.; CUNHA, T. J. F.; SALTON, J. C. Attributes of fertility and humic fractions of an distroferric Red Latosol in the Cerrado. Pesquisa Agropecuária Brasileira, Brasília, v. 41, n. 5, p. 847-853, 2006.

FONTANA, A.; NASCIMENTO, G. B.; ANJOS, L. H. C.; PEREIRA, M. G.; EBELING, A. G. Organic matter soils of Tabuleiros in Northern Fluminense (RJ). UFRRJ, Revista Floresta e Ambiente, Seropédica, v. 8, n. 1, p. 114-119, 2001.

LOSS, A.; PEREIRA, M. G.; SCHULTZ, N.; ANJOS, L. H. C.; SILVA, E. M. R. Quantification of carbon from humic substances in different use systems soil and evaluation periods. Bragantia, Campinas, v. 69, n. 4, p. 913-922, 2010.
PINHEIRO, E. F. M.; PEREIRA, M. G.; ANJOS, L. H. C.; PALMIERI, F.; SOUZA, R. C. de. Organic matter in red latossol under different tillage systems and soil coverage. Revista Brasileira de Agrociência, Pelotas, v. 9, n. 1, p. 53-56, 2003.

PULROLNIK, K.; BARROS, N. F.; SILVA, I. R.; NOVAIS, R. F.; BRANDANI, C. B. Carbon and nitrogen pools in soil organic matter under eucalypt, pasture and savanna vegetation in Brazil. Revista Brasileira de Ciências do Solo, Viçosa, MG, v. 33, n. 5, p. 1125-1136, 2009.

RANGEL, O. J. P.; SILVA, C. A. Carbon and nitrogen storage and organicfractions in latosol submitted to different use and management systems. Revista Brasileira de Ciências do Solo, Viçosa, MG. v. 31, n. 6, p. 1609-1623, 2007.

RASSE, D. P.; RUMPEL, C.; DIGNAC, M. F. Is soil carbon mostly root carbon? Mechanisms for a specific stabilization. Plant and Soil, Dordrecht, v. 269, n. 1-2, p. 341-356, 2005

RIBEIRO JÚNIOR, J. I.; DE MELO, A. L. P. Practical guide for SAEG use. Viçosa: Folha, 2008. 288 p.

SÁ, J. C. DE M.; CERRI, C. C.; DICK, A. W.; LAL, R.; VENSKE FILHO, S. P.; PICCOLO, M. C.; FEIGL, B. E. Soil organic matter dynamics and sequestration rates for a tillage chronosequence in a Brazilian Oxisol. Soil Science Society American Journal, Madison, v. 65, n. 5, p. 1476-1499, 2001.

SILVA, I. F.; MIELNICZUK, J. Evaluation of the state of aggregation of soil affected by agricultural use. Revista Brasileira de Ciência Solo, Viçosa, MG, v. 21, n. 2, p. 313-319, 1997.

SILVA, I. R.; MENDONÇA, E. S. Soil organic matter. In: NOVAIS, R. F.; ALVAREZ V., V. H.; BARROS, N. F.; FONTES, R. L. F.; CANTARUTTI, R. B.; NEVES, J. C. L. Soil fertility. Viçosa, MG, Sociedade Brasileira de Ciência do Solo, 2007. p. 275-374.

SIQUEIRA NETO, M.; PICCOLO, M. C.; SCOPEL, E.; COSTA JÚNIOR, C.; CERRI, C. C.; BERNOUX, M. Total soil carbon and chemical attributes under different land uses in the Brazilian savanna. Acta Scientiarum Agronomy, Maringá, v. 31, n. 4, p. 709-717, 2009a.

SIQUEIRA NETO, M.; VENZKE FILHO, S. P.; PICCOLO, M. C.; CERRI, C. E. P.; CERRI, C. C. Quantification of carbon from humic substances in different use systems in rotation crops in no-tillage system in Tibagi (PR) - Carbon Sequestration in Soil. Revista Brasileira de Ciência Solo, Viçosa, MG, v. 33, n. 4, p. 1013-1022, 2009b. 
SJÖBERG, G.; KNICKER, H.; NILSSON, S. I.; BERGGREN, D. Impact of long-term $\mathrm{N}$ fertilization on the structural composition of spruce litter and mor humus. Soil Biology and Biochemistry, Oxford, v. 36, n. 4, p. 609-618, 2004.

SOUZA, E. D.; CARNEIRO, M. A. C.; PAULINO, H. B.; SILVA, C. A.; BUZETTI, S. Alterations in carbon fractions in a Typic Quartzipisamment under different systems of soil management. Acta Scientiarum Agronomy, Maringá, v. 28, n. 3, p. 323-329, 2006.

STEINER, F.; PIVETTA, L. A.; ZOZ, T.; PINTO JUNIOR, A. S. Organic carbon stock in soil affected by organic fertilization and cropping systems in southern Brazil. Semina: Ciências Agrárias, Londrina, v. 33, p. 2775-2788, 2012. Suplemento 1.
STEVENSON, F. J. Humus chemistry: genesis, composition, reactions. New York: J. Wiley, 1994. 496 p.

SWIFT, R. S. Sequestration of carbon by soil. Soil Science, United States, v. 166, n. 11, p. 858-871, 2001.

VEZZANI, F. M.; MIELNICZUK, J. Soil aggregation and carbon storage of a paleudult under different agricultural managaments. Revista Brasileira de Ciências do Solo, Viçosa, MG, v. 35, n. 1, p. 213-226, 2011.

YEOMANS, J. C.; BREMNER, J. M. A rapid and precise method for routine determination of organic carbon in soil. Comm. Soil Science And Plant Analysis, London, v. 19, n. 13, p. 1467-1476, 1988. 